\title{
Characteristics and Preparation of PVDF Catalytic Membrane Modified by $\mathrm{Nano}-\mathrm{TiO}_{2} / \mathrm{Fe}^{3+}$
}

\author{
Xi Lijun ${ }^{1}$, Zhang $\mathrm{Li}^{1}$, $\mathrm{Li} \mathrm{Li}^{1}$, Chi Jingyuan ${ }^{1}$, Lu Junchi ${ }^{1}$, Tian $\mathrm{Ye}^{1}$ and Zhang Yingjie ${ }^{*}, 1,2$ \\ ${ }^{1}$ School of Chemical Engineering, Northeast Dianli University, P. O. Box 81, JiLin 132012, PR, China \\ ${ }^{2}$ National Engineering Research Center of Urban Water Resources, State Key Laboratory of Urban Water Resource and \\ Environment, Harbin Institute of Technology, P.O. Box 2627, Harbin 150090, PR, China
}

\begin{abstract}
The polyvinylidene fluoride (PVDF)/ $\mathrm{Fe}^{3+}-\mathrm{TiO}_{2}$ catalytic membrane was prepared by sol-gel method. It was characterized by X-ray diffraction (XRD), scanning electron microscopy (SEM), FT-IR spectrum (FT-IR), mechanics capability, water flux, pepsin retention, porosity and contact angle etc. The catalytic activity of $\mathrm{PVDF} / \mathrm{Fe}^{3+}-\mathrm{TiO}_{2}$ catalytic membrane was evaluated by the degradation of refractory dye Orange IV in the presence of $\mathrm{H}_{2} \mathrm{O}_{2}$. The results show that the addition of appropriate nano-sized $\mathrm{TiO}_{2}$ sol in the preparation of PVDF membrane has greatly improved some properties of the membrane such as microstructure, hydrophilic ability, mechanics intensity and water flux etc. The addition of $\mathrm{Fe}^{3+}$ ion in the preparation of PVDF membrane has greatly improved its catalytic activity to decompose $\mathrm{H}_{2} \mathrm{O}_{2}$. The catalytic activity of $\mathrm{PVDF} / \mathrm{Fe}^{3+}-\mathrm{TiO}_{2}$ is increased with the increase of the content of $\mathrm{Fe}^{3+}$ ion. When the content of $\mathrm{Fe}^{3+} \mathrm{TiO}_{2}$ sol is $21 \%$, the content of $\mathrm{Fe}^{3+}$ ion is from $0.02 \%$ to $0.12 \%$, the discolorization rate of Orange IV in this Fenton-like oxidation is from $61.2 \%$ to $90.5 \%$. The catalytic activity of $\mathrm{PVDF} / \mathrm{Fe}^{3+}-\mathrm{TiO}_{2}$ is not changed with the increase of the content of nano-sized $\mathrm{TiO}_{2}$. This kind of $\mathrm{PVDF} / \mathrm{Fe}^{3+}-\mathrm{TiO}_{2}$ catalytic membrane has not only good filtration efficiency but also good catalytic activity to effectively decompose $\mathrm{H}_{2} \mathrm{O}_{2}$.
\end{abstract}

Keywords: Modified PVDF membrane, catalytic oxidation, Fenton-like, $\mathrm{TiO}_{2}$, hydroxyl radical.

\section{INTRODUCTION}

The polyvinylidene fluoride (PVDF) membrane for its non-toxic, chemical stability, has been widely used in the field of water separation processes as ultra filtration membrane [1]. Some studies of PVDF ultra filtration membrane are mainly focused on improving its hydrophilic properties [2-4], anti-pollution [5] and magnetic properties [6], but the modified PVDF membrane to catalyze $\mathrm{H}_{2} \mathrm{O}_{2}$ as Fenton agent has not been reported till now.

The modified PVDF membrane prepared by sol-gel method is a kind of organic-inorganic hybrid membrane. There have been some literatures to report the modified PVDF membrane prepared by the addition of $\mathrm{ZrO}_{2}, \mathrm{Al}_{2} \mathrm{O}_{3}$ and $\mathrm{TiO}_{2}$ nanoparticles [7-10]. Nano-sized $\mathrm{TiO}_{2}$ can effectively improve surface polarity of PVDF membrane [11]. Madaeni and Ghaemi [12] have reported that the RO membranes coated with $\mathrm{TiO}_{2}$ particles have the self-cleaning property under UV irradiation. The photo-catalytic properties of $\mathrm{TiO}_{2} / \mathrm{PVDF}$ membrane could be improved through the doping of $\mathrm{Fe}^{3+}$ ion, which introduced defects grid position or changed the crystalline structure in nanometer $\mathrm{TiO}_{2}$, and thereby reduced the recombination of electron and optical cavities [13-16] The modified PVDF membrane by the addition of $\mathrm{Fe}^{3+}-\mathrm{TiO}_{2}$ as Fenton agent has not been reported

*Address correspondence to this author at the School of Chemical Engineering, Northeast Dianli University, P. O. Box 81, JiLin 132012, PR, China;

Tel: 86-432-64807317; Fax: 86-432-64806620;

E-mail: zhangyingjie@mail.nedu.edu.cn till now. The main objective of present study is to investigate the preparation and characterization of $\mathrm{PVDF} / \mathrm{Fe}^{3+}-\mathrm{TiO}_{2}$ catalytic membrane and investigated its catalytic activity to decompose $\mathrm{H}_{2} \mathrm{O}_{2}$.

\section{EXPERIMENT}

\subsection{Materials and Reagents}

PVDF powder (Chenguang Chemical Engineering Institute), butyl titanate, DMAc, EtOH, glacial acetic acid, $\mathrm{Fe}\left(\mathrm{NO}_{3}\right)_{3} \cdot 9 \mathrm{H}_{2} \mathrm{O}, 30 \% \mathrm{H}_{2} \mathrm{O}_{2}$, Orange IV, pepsin and other chemicals were of analytical grade and used without further purification. The $\mathrm{pH}$ of the solution was adjusted by a diluted aqueous solution of $\mathrm{NaOH}$ or $\mathrm{HNO}_{3}$.

\subsection{Preparation of $\mathrm{PVDF} / \mathrm{Fe}^{3+}-\mathrm{TiO}_{2}$ Catalytic Membrane}

First, it is to mix $22.0 \mathrm{~mL}$ of tetrabutyl titanate, $22.0 \mathrm{~mL}$ of anhydrous ethanol and $12.0 \mathrm{~mL}$ of glacial acetic acid to get the solution A. The solution $\mathrm{B}$ is to $\operatorname{mix} 10 \mathrm{~mL}$ of a definite concentration $\mathrm{Fe}\left(\mathrm{NO}_{3}\right)_{3}$ solution and $10.0 \mathrm{~mL}$ Ethanol. The $\mathrm{pH}$ of solution $\mathrm{A}$ and $\mathrm{B}$ is 3.0 adjusted by $\mathrm{HNO}_{3}$. The $\mathrm{TiO}_{2}$ sol doped with $\mathrm{Fe}^{3+}$ is prepared by adding the solution B into solution A at the speed of $1 \mathrm{drop} / \mathrm{s}$ in stir.

The casting membrane solution is composed of PVDF, DMAc and a definite mass of $\mathrm{TiO}_{2}$ sol with mass ratio of PVDF: DMAc=14: 84. It was stired for a period of time, and then deaerated to film.

\subsection{Membrane Testing and Characterization}

The catalytic activity of $\mathrm{PVDF} / \mathrm{Fe}^{3+}-\mathrm{TiO}_{2}$ membrane to catalyze $\mathrm{H}_{2} \mathrm{O}_{2}$ was evaluated by the degradation of Orange 
IV and the decomposition of $\mathrm{H}_{2} \mathrm{O}_{2}$. The concentration of Orange IV was analyzed with Unico Double Beam UV-4802 $\mathrm{UV} / \mathrm{Vis}$ spectrophotometer at $440 \mathrm{~nm}$. Hydrogen peroxide $\left(\mathrm{H}_{2} \mathrm{O}_{2}\right)$ was analyzed by titanium oxalate spectrophotometry [17]. The static experiments were conducted in a thermostated shaker at $25^{\circ} \mathrm{C}$. Each experiment was repeated for two times and an average value was calculated. The $\mathrm{pH}$ value was monitored by a $\mathrm{pHs}-3 \mathrm{C} \mathrm{pH}$ meter.

The water flux was measured on Shanghai Mosu ultra filtration cup system. The contact angle measurement was measured on SL 2008 apparatus. The membrane morphology was measured on HITACHI S-520 scanning electron microscope (SEM). The composition of catalytic membrane was measured on Rigaku X-ray diffraction.

\section{RESULTS AND DISCUSSION}

\subsection{Membrane Catalytic Activity}

\subsubsection{Effect of Mass Ratio of $\mathrm{Fe}^{3+} / \mathrm{TiO}_{2}$ on the Catalytic Activity of Membrane}

When the mass concentration of $\mathrm{Fe}^{3+}{ }_{-} \mathrm{TiO}_{2}$ sol in the casting solution is $21 \%$, the effect of mass ratio of $\mathrm{Fe}^{3+} / \mathrm{TiO}_{2}$ on the decomposition of $\mathrm{H}_{2} \mathrm{O}_{2}$ was investigated, the results are shown in Fig. (1). The effect of mass ratio of $\mathrm{Fe}^{3+} / \mathrm{TiO}_{2}$ on the discolorization of Orange IV is shown in Fig. (2). It can be seen that the decomposition rate of $\mathrm{H}_{2} \mathrm{O}_{2}$ increased with the increase of mass ratio of $\mathrm{Fe}^{3+} / \mathrm{TiO}_{2}$ from 1:65 to 1:9 in $\mathrm{Fe}^{3+} \mathrm{TiO}_{2}$ sol, but the decomposition rate of $\mathrm{H}_{2} \mathrm{O}_{2}$ decreased with the increase of mass ratio of $\mathrm{Fe}^{3+} / \mathrm{TiO}_{2}$ from $1: 9$ to $1: 6$, indicating that the optimum mass ratio of $\mathrm{Fe}^{3+} / \mathrm{TiO}_{2}$ is 1:9 in $\mathrm{Fe}^{3+}{ }_{-} \mathrm{TiO}_{2}$ sol.

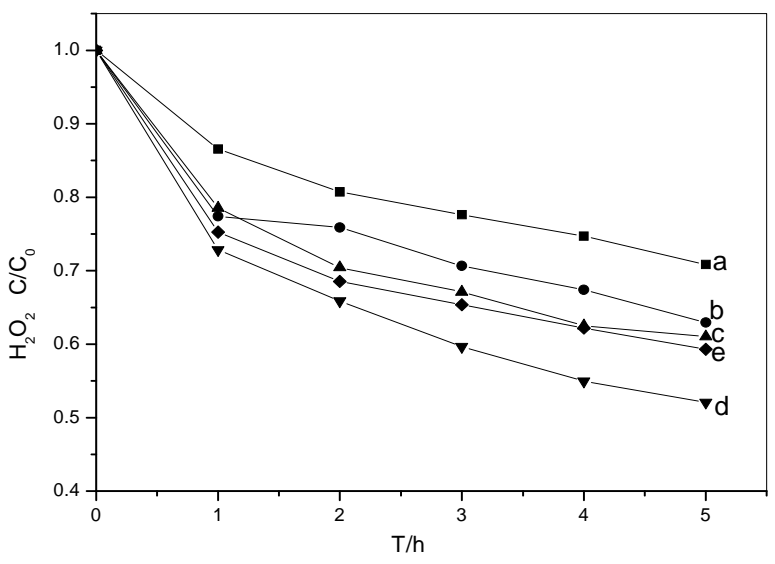

Fig. (1). Effect of different $\mathrm{Fe}^{3+} / \mathrm{TiO}_{2}$ ratio on the decomposition of $\mathrm{H}_{2} \mathrm{O}_{2}$. Operational initial conditions: [Orange IV] $=0.4 \mathrm{mM} 50 \mathrm{~mL}$; $\left[\mathrm{H}_{2} \mathrm{O}_{2}\right]=15 \mathrm{mM} ; \mathrm{pH}=4.5$; Temperature $=20^{\circ} \mathrm{C}$. (a) $\mathrm{Fe}^{3+}: \mathrm{TiO}_{2}=1: 65$; (b) $\mathrm{Fe}^{3+}: \mathrm{TiO}_{2}=1: 22$; (c) $\mathrm{Fe}^{3+}: \mathrm{TiO}_{2}=1: 13$; (d) $\mathrm{Fe}^{3+}: \mathrm{TiO}_{2}=1: 9$; (e) $\mathrm{Fe}^{3+}: \mathrm{TiO}_{2}=1: 6$.

As can be seen from Fig. (2), the discolorization rate of Orange IV increased from $61.2 \%$ to $90.5 \%$ with the increase of mass ratio of $\mathrm{Fe}^{3+} / \mathrm{TiO}_{2}$ from 1:65 to 1:9 in $\mathrm{Fe}^{3+}{ }_{-} \mathrm{TiO}_{2}$ sol, which is corresponding to the Fig. (1). The discolorization rate of Orange IV changed a little for the cases of mass ratio of $\mathrm{Fe}^{3+} / \mathrm{TiO}_{2}$ from 1:9 to $1: 6$. This suggested that the catalytic activity of $\mathrm{PVDF} / \mathrm{Fe}^{3+}-\mathrm{TiO}_{2}$ membrane is mainly depended on the $\mathrm{Fe}^{3+}$ content in the casting solution. The more concentration of $\mathrm{Fe}^{3+}$ content, the more catalytic activity of $\mathrm{PVDF} / \mathrm{Fe}^{3+}-\mathrm{TiO}_{2}$ is under a definite concentration range of $\mathrm{Fe}^{3+}$.

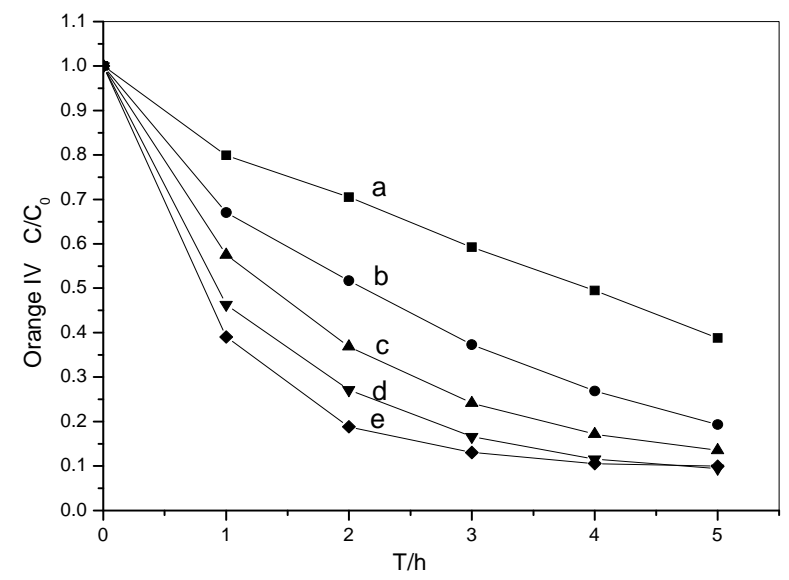

Fig. (2). Effect of different $\mathrm{Fe}^{3+} / \mathrm{TiO}_{2}$ ratio on the removal of Orange IV. Operational initial conditions: [Orange IV] $=0.4 \mathrm{mM} 50$ $\mathrm{mL} ; \quad\left[\mathrm{H}_{2} \mathrm{O}_{2}\right]=15 \quad \mathrm{mM} ; \quad \mathrm{pH}=4.5 ; \quad$ Temperature $=20^{\circ} \mathrm{C}$. (a) $\mathrm{Fe}^{3+}: \mathrm{TiO}_{2}=1: 65 ;$ (b) $\mathrm{Fe}^{3+}: \mathrm{TiO}_{2}=1: 22 ;$ (c) $\mathrm{Fe}^{3+}: \mathrm{TiO}_{2}=1: 13$;(d) $\mathrm{Fe}^{3+}: \mathrm{TiO}_{2}=1: 9 ;$ (e) $\mathrm{Fe}^{3+}: \mathrm{TiO}_{2}=1: 6$.

\subsubsection{Effect of Concentration of $\mathrm{Fe}^{3+}{ }_{-} \mathrm{TiO}_{2}$ Sol on the Catalytic Activity of Membrane}

When the mass ratio of $\mathrm{Fe}^{3+} / \mathrm{TiO}_{2}$ is $1: 9$ in $\mathrm{Fe}^{3+}{ }_{-} \mathrm{TiO}_{2}$ sol, the effect of concentration of $\mathrm{Fe}^{3+}{ }_{-} \mathrm{TiO}_{2}$ sol in casting solution on the decomposition of $\mathrm{H}_{2} \mathrm{O}_{2}$ was investigated, the results are shown in Fig. (3). The effect of concentration of $\mathrm{Fe}^{3+}{ }_{-} \mathrm{TiO}_{2}$ in casting solution on the discolorization of Orange IV is shown in Fig. (4). It can be seen that the decomposition rate of $\mathrm{H}_{2} \mathrm{O}_{2}$ increased with the increase of concentration of $\mathrm{Fe}^{3+} \mathrm{TiO}_{2}$ sol from $4 \%$ to $27 \%$ in casting solution, but the decomposition rate of $\mathrm{H}_{2} \mathrm{O}_{2}$ changed a little with the increase of concentration of $\mathrm{Fe}^{3+} \mathrm{TiO}_{2}$ sol from $21 \%$ to $27 \%$, indicating that the optimum concentration of $\mathrm{Fe}^{3+}{ }_{-} \mathrm{TiO}_{2}$ sol in casting solution is $21 \%$ in casting solution.

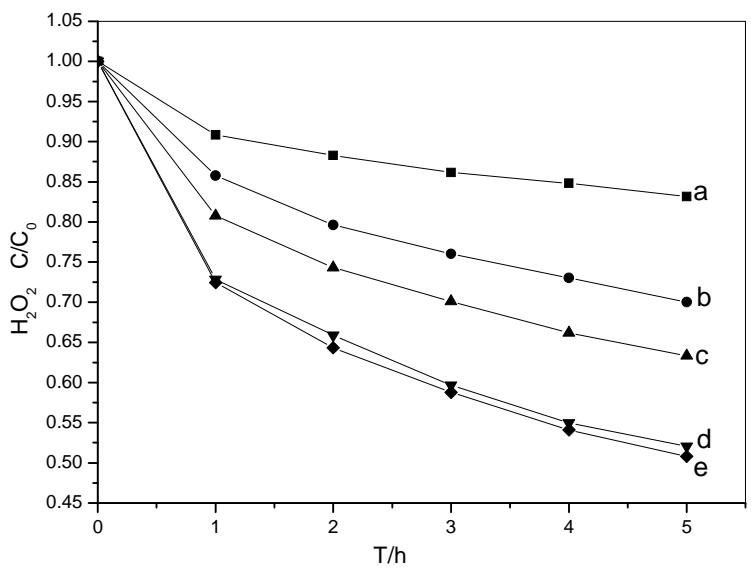

Fig. (3). Effect of different concentration sol on the decomposition of $\mathrm{H}_{2} \mathrm{O}_{2}$. Operational initial conditions: [Orange IV] $=0.4 \mathrm{mM} 50$ $\mathrm{mL} ;\left[\mathrm{H}_{2} \mathrm{O}_{2}\right]=15 \mathrm{mM} ; \mathrm{pH}=4.3$; Temperature $=20^{\circ} \mathrm{C}$. (a) $4 \%$; (b) $12 \%$; (c) $19 \%$; (d) $21 \%$; (e) $27 \%$. 


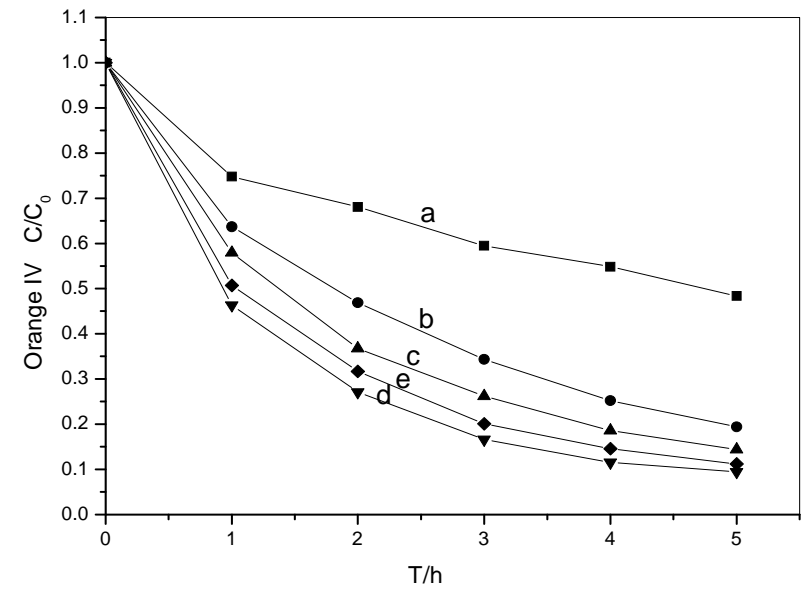

Fig. (4). Effect of different concentration sol on the degradation of Orange IV. Operational initial conditions: [Orange IV] $=0.4 \mathrm{mM} 50$ $\mathrm{mL} ;\left[\mathrm{H}_{2} \mathrm{O}_{2}\right]=15 \mathrm{mM} ; \mathrm{pH}=4.3$; Temperature $=20^{\circ} \mathrm{C}$. (a) $4 \%$; (b) $12 \%$; (c) $19 \%$; (d) $21 \%$;(e) $27 \%$.

As can be seen from Fig. (4), the discolorization rate of Orange IV increased with the increase of concentration of $\mathrm{Fe}^{3+} \mathrm{TiO}_{2}$ sol, which is corresponding to the Fig. (3). However, the discolorization rate of Orange IV decreased with the increase of concentration of $\mathrm{Fe}^{3+}{ }_{-} \mathrm{TiO}_{2}$ sol from $21 \%$ to $27 \%$, indicating that the optimum concentration of $\mathrm{Fe}^{3+} \mathrm{TiO}_{2}$ sol is $21 \%$ in casting solution. Another experiment showed that the catalytic activity of $\mathrm{PVDF} / \mathrm{Fe}^{3+}$ $\mathrm{TiO}_{2}$ is not changed with the increase of the content of nanosized $\mathrm{TiO}_{2}$. So the catalytic activity of $\mathrm{PVDF} / \mathrm{Fe}^{3+}-\mathrm{TiO}_{2}$ is mainly depended on the concentration of $\mathrm{Fe}^{3+}$ ion rather than the concentration of $\mathrm{TiO}_{2}$.

\subsection{Characteristics of $\mathrm{PVDF} / \mathrm{Fe}^{3+}-\mathrm{TiO}_{2}$ Membrane}

\subsubsection{XRD Measurement}

The XRD spectrums of $\mathrm{PVDF} / \mathrm{Fe}^{3+}-\mathrm{TiO}_{2}$ catalytic membrane, pure PVDF membrane and nano-sized $\mathrm{TiO}_{2} / \mathrm{Fe}^{3+}$ are shown in Fig. (5). The diffraction peaks in pure PVDF membrane are in $2 \theta$ of $20.5^{\circ}, 36.5^{\circ}$ and $40.8^{\circ}$. The diffraction peaks in nano-sized $\mathrm{TiO}_{2} / \mathrm{Fe}^{3+}$ are in $2 \theta$ of $25.1^{\circ}$, $38.0^{\circ}, 48.2^{\circ}$ and $55.0^{\circ}$. The diffraction peaks in $\mathrm{PVDF} / \mathrm{Fe}^{3+}$ $\mathrm{TiO}_{2}$ catalytic membrane are composed of the diffraction peaks of $\mathrm{TiO}_{2} / \mathrm{Fe}^{3+}$ and pure PVDF membrane. This showed that there were nano-sized $\mathrm{TiO}_{2}$ crystals formed in the preparation of $\mathrm{PVDF} / \mathrm{Fe}^{3+}-\mathrm{TiO}_{2}$ catalytic membrane.

\subsubsection{SEM Measurement}

The morphology of cross section of $\mathrm{PVDF} / \mathrm{Fe}^{3+}-\mathrm{TiO}_{2}$ membrane with different concentration of $\mathrm{Fe}^{3+}{ }_{-} \mathrm{TiO}_{2}$ sol was measured on the SEM, the results are shown in Fig. (6). It can be seen that the asymmetric property of membrane decreased with the increase of concentration of $\mathrm{Fe}^{3+} \mathrm{TiO}_{2}$ sol in casting solution, the cortical layer of membrane thickened, the finger hole in the membrane decreased, and the mesh hole increased. This showed that the addition of $\mathrm{Fe}^{3+}{ }_{-} \mathrm{TiO}_{2}$ sol made the phase inversion speed rate slow to depress the formation of finger hole and to increase the formation of mesh hole in membrane. This will benefit to enhance and improve the service performance of $\mathrm{PVDF} / \mathrm{Fe}^{3+}-\mathrm{TiO}_{2}$ membrane.

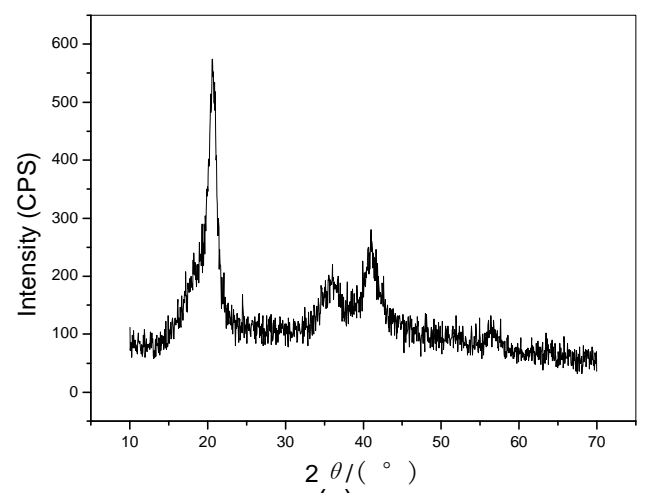

(a)

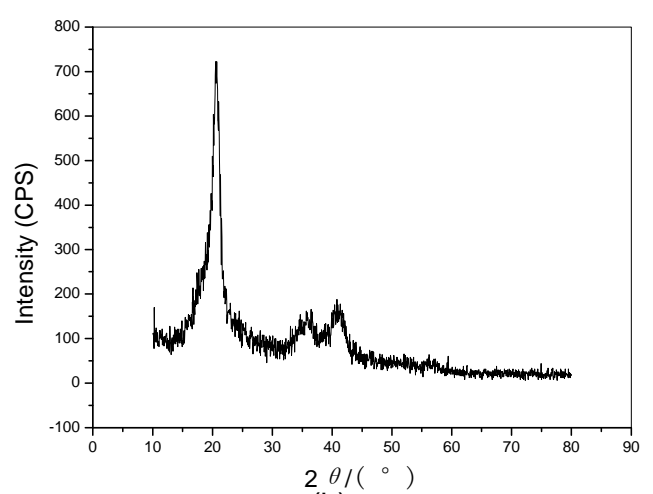

(b)

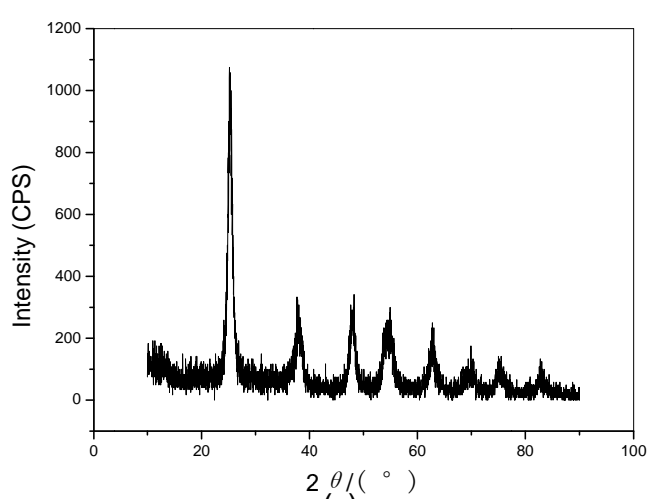

(c)

Fig. (5). XRD spectrum of $\mathrm{PVDF} / \mathrm{Fe}^{3+}-\mathrm{TiO}_{2}$ catalytic membrane, pure PVDF membrane and $\mathrm{TiO}_{2}$ doped $\mathrm{Fe}^{3+}$. (a) $\mathrm{Fe}^{3+} / \mathrm{TiO}_{2}$; (b) $\mathrm{PVDF} / \mathrm{Fe}^{3+}-\mathrm{TiO}_{2}$ catalytic membrane; (c) pure PVDF membrane.

\subsubsection{Water Flux, Pepsin Retention and Contact Angle of $\mathrm{PVDF} / \mathrm{Fe}^{3+}-\mathrm{TiO}_{2}$ Membrane}

The water flux, the intercept of pepsin and the contact angle of $\mathrm{PVDF} / \mathrm{Fe}^{3+}-\mathrm{TiO}_{2}$ catalytic membrane are shown in Tables $\mathbf{1}$ and $\mathbf{2}$. 


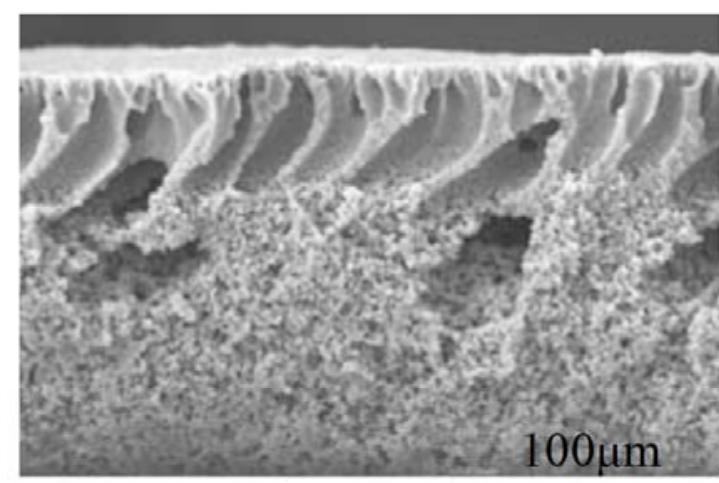

(a)

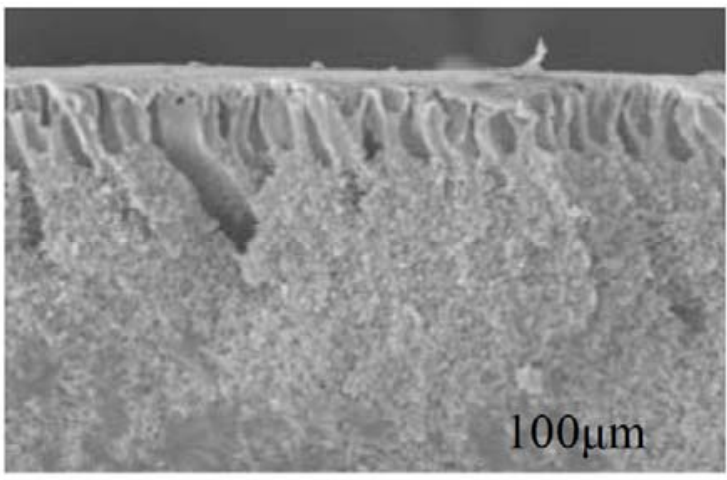

(b)

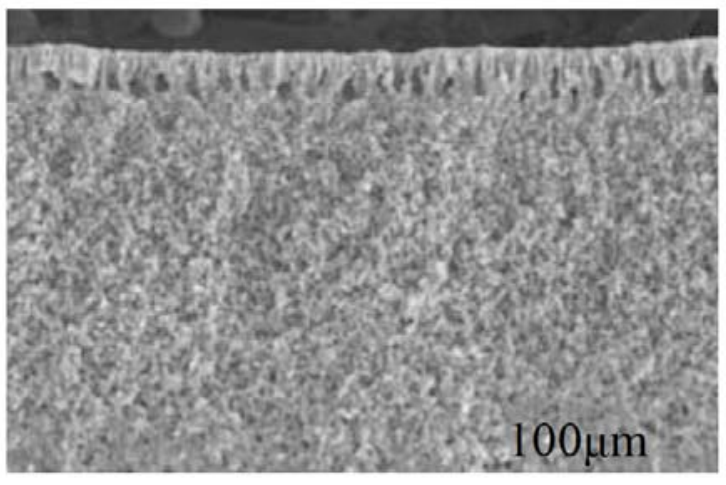

Fig. (6). SEM micrographs of $\mathrm{PVDF} / \mathrm{Fe}^{3+}{ }_{-} \mathrm{TiO}_{2}$ membrane with different concentration of $\mathrm{Fe}^{3+}{ }_{-} \mathrm{TiO}_{2}$ sol. (a) $0 \%$; (b) $4 \%$; (c) $21 \%$.

It can be seen that the water flux of $\mathrm{PVDF} / \mathrm{Fe}^{3+}-\mathrm{TiO}_{2}$ catalytic membrane increased with the increase of the concentration of $\mathrm{Fe}^{3+}-\mathrm{TiO}_{2}$ sol from 0 to $15 \%$ and from $19 \%$ to $27 \%$, the maximum water flux is $955.23 \mathrm{~L} /\left(\mathrm{m}^{2} \cdot \mathrm{h}\right)$ at the concentration of $\mathrm{Fe}^{3+}-\mathrm{TiO}_{2}$ sol $15 \%$. Losito et al. [18] thought that the $\mathrm{Fe}^{3+}{ }_{-} \mathrm{TiO}_{2}$ sol contained a large number of hydroxyl radicals to improve the surface polarity, thus to increase the water flux of membrane. Kim et al. [19] thought that a definite amount of $\mathrm{Fe}^{3+}{ }_{-} \mathrm{TiO}_{2}$ sol was a kind of heterogeneous deposition agent to transfer the finger hole to the mesh hole, thus to decrease the water flux of membrane.

In addition, the addition of $\mathrm{Fe}^{3+}{ }_{-} \mathrm{TiO}_{2}$ sol made the pepsin retention of the membrane changed. Ren et al. [20] considered that the reunion and disperse of in the membrane formed finger hole and mesh hole respectively, thus to lead to the difference of pepsin retention of the membrane.
Table 1. The Water Flux, Pepsin Retention and Contact Angle of $\mathrm{PVDF} / \mathrm{Fe}^{3+}-\mathrm{TiO}_{2}$ Catalytic Membrane of Different Mass Ratio of $\mathrm{Fe}^{3+}{ }_{-} \mathrm{TiO}_{2}$ sol

\begin{tabular}{|c|c|c|c|}
\hline $\begin{array}{c}\text { Mass Ratio of } \\
\mathbf{F e}^{\mathbf{3 +}} \mathbf{T i O}_{\mathbf{2}} \mathbf{s o l}\end{array}$ & $\begin{array}{c}\text { Water Flux } \\
\left(\mathbf{L} \cdot \mathbf{m}^{-2} \cdot \mathbf{h}^{-\mathbf{1}}\right)\end{array}$ & $\begin{array}{c}\text { Pepsin Retention } \\
\mathbf{\%}\end{array}$ & $\begin{array}{c}\text { Contact Angle } \\
\left({ }^{\circ}\right)\end{array}$ \\
\hline \hline $0 \%$ & 207.82 & 69.65 & 77.4 \\
\hline $4 \%$ & 310.77 & 75.86 & 75.6 \\
\hline $8 \%$ & 579.95 & 77.24 & 74.8 \\
\hline $15 \%$ & 955.23 & 58.62 & 72.6 \\
\hline $19 \%$ & 459.41 & 73.10 & 70.9 \\
\hline $21 \%$ & 521.32 & 82.07 & 68.5 \\
\hline $27 \%$ & 853.64 & 37.93 & 68.1 \\
\hline
\end{tabular}

Table 2. The Water Flux, Pepsin Retention and Contact Angle of $\mathrm{PVDF} / \mathrm{Fe}^{3+}-\mathrm{TiO}_{2}$ Catalytic Membrane of Different Mass Ratio of the $\mathrm{Fe}^{3+} / \mathrm{TiO}_{2}$ in $\mathrm{Fe}^{3+}{ }_{-} \mathrm{TiO}_{2}$ sol

\begin{tabular}{|c|c|c|c|}
\hline Sample & $\begin{array}{c}\text { Water Flux } \\
\left(\mathbf{L} \cdot \mathbf{m}^{-2} \cdot \mathbf{h}^{-1}\right)\end{array}$ & $\begin{array}{c}\text { Pepsin Retention } \\
\%\end{array}$ & $\begin{array}{c}\text { Contact Angle } \\
\left({ }^{\circ}\right)\end{array}$ \\
\hline \hline pure PVDF & 207.82 & 69.65 & 77.4 \\
\hline $\mathrm{Fe}^{3+}: \mathrm{TiO}_{2}=1: 65$ & 151.36 & 64.83 & 73.8 \\
\hline $\mathrm{Fe}^{3+}: \mathrm{TiO}_{2}=1: 9$ & 521.32 & 82.07 & 68.5 \\
\hline
\end{tabular}

The contact angle of $\mathrm{PVDF} / \mathrm{Fe}^{3+}-\mathrm{TiO}_{2}$ catalytic membrane decreased with the increase of the concentration of $\mathrm{Fe}^{3+}{ }_{-} \mathrm{TiO}_{2}$ sol in casting membrane solution, which is due to the hydrophilicity of membrane improved by the introduction of a certain amount of hydroxyl radical [21]. But the decrease of contact angle was not significant because of the incomplete crystallization of nano-sized $\mathrm{TiO}_{2} / \mathrm{Fe}^{3+}$ and the existence of various kinds of defects in crystal.

From Table 2, when the mass ratio of $\mathrm{Fe}^{3+} / \mathrm{TiO}_{2}$ is 1:9, the performance of $\mathrm{PVDF} / \mathrm{Fe}^{3+}-\mathrm{TiO}_{2}$ catalytic membrane is the best.

\section{CONCLUSIONS}

A $\mathrm{TiO}_{2}$ sol doped with $\mathrm{Fe}^{3+}$ in the dispersion was prepared by using sol - gel in situ mixing method. The $\mathrm{Fe}^{3+}{ }_{-} \mathrm{TiO}_{2}$ sol was added into the PVDF casting solution with various contents and different $\mathrm{Fe}^{3+} / \mathrm{TiO}_{2}$ proportions. Thus, a series of $\mathrm{PVDF} / \mathrm{Fe}^{3+}-\mathrm{TiO}_{2}$ catalytic membrane are obtained by phase inversion technology. There is a notable improvement in the microstructure and the ultra filtration properties of (PVDF)/ $/ e^{3+}-\mathrm{TiO}_{2}$ catalytic membrane compared with the PVDF membrane. The results of XRD and SEM measurements showed that the nano-sized $\mathrm{Fe}^{3+} / \mathrm{TiO}_{2}$ particles in the PVDF membrane would depress the formation of finger holes, and would benefit to form mesh holes to certain extents. Furthermore, the hydrophilicity of $\mathrm{PVDF} / \mathrm{Fe}^{3+}-\mathrm{TiO}_{2}$ also has notable improvement. With the increase of $\mathrm{Fe}^{3+}{ }_{-} \mathrm{TiO}_{2}$ sol contents and the increase of $\mathrm{Fe}^{3+}$ content in the $\mathrm{Fe}^{3+}-\mathrm{TiO}_{2}$ sol, the 
catalytic activity of the membrane increased for the decolorization rate of Orange IV from $51.6 \%$ to $90.5 \%$.

\section{CONFLICT OF INTEREST}

The authors confirm that this article content has no conflict of interest.

\section{ACKNOWLEDGEMENTS}

This work is supported by the National Natural Science Foundation of China (No.50978067), the 11th five-year specific events of water (2008ZX07421-002, 2009ZX07424005, 2009ZX07424-006) and the Science and Technology Development Program of Jilin Province (20116022).

\section{REFERENCES}

[1] Liu Chun T, Jin Z, Hou HG, et al. Research progress in PVDF ultra-filtration membranes prepared by phase inversion method and their modifications. Chem Adhes 2009; 36(6): 54-7.

[2] Miao XY, Li JS, Wang LJ, Sun XY. Review on hydrophilic modification of poly (vinylidene fluoride) membranes. Mater Rev 2006; 3: 56-9.

[3] Li X, Lu XF, Shi LQ, et al. Surface hydrophilicity of PVDF ultra filtration membrane by simultaneous $\gamma$-ray grafting copolymerization. J Radiat Res Radiat Proc 2007;2: 65-9.

[4] Wei LC, Liu Z, Zhou J. Research progress of hydrophilic modification of poly (vinylidene fluoride) separation membranes. New Chem Mater 2008; 10: 7-9.

[5] Xiao J, Zhao X Y, Tan G Z. Effect of $\mathrm{SiO}_{2}$ nanoparticles on polyvinylidene fluoride (PVDF) ultrafiltration membrane. Mater Sci Eng 2008; 2(1): 5-8

[6] Li LL. Study on magnetic $\mathrm{PSF} / \mathrm{CoFe}_{2} \mathrm{O}_{4}$ composite ultra filtration membrane. Membr Sci Technol 2008; 28(5): 11-15.

[7] Bottion A, Capannelli G, Comite A. Preparation a characterization of novel porous PVDF- $\mathrm{ZrO}_{2}$ composite membrances. Desalinat-ion 2002; 146: 35-40
[8] Yan L, Li Y S, Xiang C B. Effect of nano-sized $\mathrm{Al}_{2} \mathrm{O}_{3}$ particles addition on PVDF ultra-filtration membrances perfomance. J Membr Sci 2006, 276:162-7.

[9] Cao XC, Ma J, Shi X, et al. Effect of $\mathrm{TiO}_{2}$ nanoparticle size on the performance of PVDF membrane. Appl Surf Sci 2006; 253: 2003 10

[10] Zhang JQ, Li Q, Fan LJ. Preparation and photocatalytic properties of $\mathrm{Fe}_{2} \mathrm{O}_{3} / \mathrm{TiO}_{2} /$ montmorillonite photocatalyst. J Henan Norm Univ (Nat Sci) 2009; 5: 79-82.

[11] He H Y. Develepment of Study on $\mathrm{TiO}_{2}$ Photocatalyst. Jiangsu Ceram 2008;41(1): 20-2.

[12] Madaeni S S, Ghaemi N. Characterization of self-cleaning RO membranes coated with $\mathrm{TiO}_{2}$ particles under UV irradiation. J Membr Sci 2007; 303: 221-33.

[13] Wang WW, Zhang ZK. The influence of $\mathrm{Fe}^{3+}$ on crystalline phase transition of $\mathrm{TiO}_{2}$. J Funct Mater 2003; 4: 429-30.

[14] Hou L, Liu K, Gao FM. Synthesis of $\mathrm{Fe}^{3+}$ doped $\mathrm{TiO}_{2}$ by Sol- Gel method and its photocatalytic activities. Bull Chin Ceram Soc 2005; 3: 46-9.

[15] Shu BT, Sun JX, Hu CL, et al. Preparation and characterization of $\mathrm{Fe}^{3+}$-doped $\mathrm{TiO}_{2}$ photocatalytic fiber materials. Acta Phys Chim Sin 2009; 8: 1561-6.

[16] Yu HM, Ding XY. Preparation and photocatalytic property of irondoped $\mathrm{TiO}_{2}$ nanoparticles. New Chem Mater 2008; 1: 67-9.

[17] Zhang YJ, Ma J. Spectrophotometric determination of hydrogen peroxide in acidic dye system with titanic oxalate. Ind Water Treat 2008; 28(11): 72-4.

[18] Losito I, Amorisco A, Palmisano F. X- ray photoelectron spectroscop characterization of composite $\mathrm{TiO}_{2}$ - poly(vinylidenefluoride) films synthesised for applications in pesticide photocatalytic degradation. Appl Surf Sci 2005, 240: 180-8.

[19] Kim KM, Park NG, Ryu KS. Characteristics of PVDF-HFP/TiO composite membrane electrolytes prepared by phase inversion and conventional casting methods. Electrochim Acta 2006;51: 5636-44.

[20] Ren P, Zhang H, Zhang GF. Study of the crystalline of the meltspinning fiber of PVDF. J Tianjin Inst Text Sci Technol 2003; 22(4): 8-10.

[21] Diebold AU. The surface science of titanium dioxide. Surf Sci Rep 2003; 48:53-229. 